\title{
TECHNOLOGY, INTERNATIONAL STRATIFICATION, AND THE POLITICS OF GROWTH
}

\author{
ALI A. MAZRUI
}

\begin{abstract}
The politics of stratification are part of the history of interdependence within and between human communities. Primitive or primordial interdependence concerns reciprocal reliance among kith and kin or within face-to-face societies. Feudo-imperial interdependence includes both feudal relations in single societies and imperial relations between societies. These are based on exploitation and hierarchy. Mature interdependence comes with egalitarianism and a rational division of labor based on equity under modern conditions.

While technology helped to demoralize individual Western societies, it also consolidated Western control of other societies. The internal democratization of the West coincided with the stratification of the world under Western dominion.

How can the Third World escape this dominion? One approach is that of disengagement; another is that of counterpenetration.

The West's Achilles' heel is its need of energy from the Third World. This need could make the West at least responsive to Third World demands for greater equity. Successful energy conservation in the West would, on the other hand, be detrimental to Third World interests in the short run.

The oil-rich Third World countries may have been cast by history as temporary leaders of the oppressed in the global system. Inequality within the Third World could be a necessary precondition for the liberation of the Third World.
\end{abstract}

The problem of stratification in history has always been linked to the tensions of interdependence. The degree to which people need each other is always at the core of their interrelationships. Theories about the consequences of the division of labor, and about the origins of caste, class, and hierarchy have all been at once concerned with issues of stratification and of interdependence.

It is clear both from the history of social institutions and of social ideas that interdependence can either create or destroy equality. The critical factor concerns the precise nature of that interdependence.

The 1973 oil crisis precipitated a reappraisal of the nature of interdependence among nations. Discussions have gone on be- 
tween the European Economic Community and the Arab oil producers concerning the possibility of exchanging European technology for Arab oil in a bid for mutually induced economic development. The American government has explored ways of strengthening relations between Western Europe and the United States in search of a new economic basis for the Atlantic partnership. The United Nations has discussed the problem of raw materials in relation to international trade, and one eminent speaker after another has called for a new definition of international interdependence.

But central to all these discussions and debates has been the ancient moral problem - the problem of equality.

In this article we distinguish three stages of interdependence: primitive, feudo-imperial, and mature. We define primitive interdependence to be the cooperative relationship which exists in conditions of rudimentary technology and limited social horizons.

The second type of interdependence is the feudo-imperial, which combines some of the characteristics of feudalism with some of the attributes of imperialism. A central characteristic of this kind of interdependence is hierarchy, and hierarchy is of course founded on the premise of inequality.

The third, or mature, stage of interdependence is one which combines sophistication with symmetry. The sophistication comes from enhanced technological capabilities and expanded social and intellectual awareness; the symmetry emerges out of a new egalitarian morality combined with a more balanced capacity for mutual harm. The different parties must not only need each other but their different needs ought to be on a scale which makes possible serious mutual dislocations in case of conflict. The combination of an egalitarian ethic and reciprocal vulnerability, within the framework of wider technological and intellectual frontiers, provides the essence of mature interdependence.

We propose to demonstrate in this article that relations among nations in the first three-quarters of this century have been primarily feudo-imperial, deprived of both the kinship solidarity of primitive interdependence and the sophisticated symmetry of 
mature interdependence. One of the most important questions confronting us is whether or not we are at last about to evolve a genuine pattern of mature interdependence before this century comes to a close.

Behind this issue is the all-powerful variable of technological change. We propose to illustrate that technological change within individual societies influenced the transition first from primitive to feudo-imperial interdependence, and then, more recently, from feudo-imperial to the beginnings of mature interdependence.

The question also arises as to whether or not technological change on the international scale could in turn facilitate in the last quarter of the twentieth century the transformation from feudoimperial relationships between the developed Northern hemisphere and the underdeveloped Southern hemisphere to interaction on a mature plane. The energy crisis may have opened up new possibilities as it revealed the inner vulnerability of feudoimperial relationships as they have hitherto existed in international affairs.

\section{TECHNOLOGICAL CHANGE AND SOCIAL IMBALANCE}

The principal factor behind Europe's rise to imperial preeminence was its technological revolution which set the stage for European expansion and colonization.

The Industrial Revolution created disparities between the Western world on the one hand and much of the rest of the world on the other. Technology within England and America from the eighteenth century onwards helped to lay the foundations of a more egalitarian England and even a more egalitarian America; yet that same technology, by increasing the inventive and productive capabilities of these societies far beyond those attained by others, initiated a process of massive disparities of income and power among the nations of the world.

Technology in the West served domestically as an equalizing process partly by destroying the traditional legitimation of hierarchy. The Industrial Revolution in England produced new challenges from the middle classes against the ancient privileges 
of the landed aristocracy. Pressures began to mount for social and political reform as trade, commerce, and expanded manufacturing capabilities produced new levels of work among the bourgeoisie. The previous revolution of the seventeenth century in England had decided the issue between king and parliament in favor of parliamentary preeminence. But, by the eighteenth and nineteenth centuries, the issue was: Who controlled parliament itself? The 1832 Great Reform Bill put forward a new basis of parliamentary composition, and therefore legislative power. As the nineteenth century entered its second half, pressures mounted for the expansion of the franchise to include the new urban proletariat. This group's enfranchisement was followed by that of rural workers as the century came to a close.

The industrial revolution itself was at the heart of these electoral and political reforms. The massive migration of people from the countryside to the cities, the growing restlessness of the newly urbanized, the pressures and social ills of new concentrations of populations, and the rise of political consciousness among the masses, all prepared the way for the process of social equalization in industrial societies. Workers began to sense the need for organization, the principle of collective bargaining entered the economic arena.

The full consolidation of trade unions in the West was not complete until the twentieth century. For a while legislation was used to discourage organization among workers. Nevertheless, the momentum of proletarian self-consciousness was under way. Both trade unions and rudimentary socialist parties began to take shape in the second half of the twentieth century in much of the Western world.

The late nineteenth century was, of course, also the period which saw the emergence of egalitarian thinkers such as Karl Marx and Friedrich Engels. New sensibilities concerning the plight of the impoverished, increased awareness of the possibilities of income distribution, and growing reluctance to see rank and status as immutable were all part of this process of technological equalization.

But the Industrial Revolution was at the same time pushing Western Europe and, later, North America further and further 
ahead in global terms. The Western world was increasing its social and economic distance from the rest of mankind, while at the same time narrowing rank and status within itself.

Three types of technology were particularly important in the rise of the West to global preeminence: that of production, of communications, and of violence. The first is what gave rise to the Industrial Revolution to begin with and what indeed defined its boundaries. The technology of communication, such as advances in seafaring, enhanced later by the invention of the steam engine, went far toward strengthening the West's capability to penetrate the rest of the world and provided the necessary preconditions for empire building.

As for the technology of violence, this gave the Western world the edge in military sophistication, resulting in the colonization of Asia and Africa. Western Europe, triumphant, created empires larger than any known in history. Its superiority in the technology of violence reinforced by the technologies of communication and production, ensured the global preeminence of the Western world in the generations which followed. The same technology which was a force for gradual equalization within the Western world itself also served to strengthen the West's domination of the rest of mankind.

Meanwhile, economic growth in the United States was laying the foundations for new levels of affluence and power. The American experience came to demonstrate even more sharply the fact that technological change was a force both for domestic equalization and international disequilibrium.

At least in rhetoric, the United States was one of the earliest modern experiments in the doctrines of both interdependence and egalitarianism. Federalism as a system of government is dominantly a doctrine of interdependence among coordinating elements. The American federal experiment brought into the arena of modern political institutions an innovative exercise in institutionalized interdependence. The original thirteen colonies later recruited additional constituent elements into this partnership to create an enduring if sometimes convulsed pluralistic polity. 
But the United States was also born on a wave of egalitarian rhetoric. The American Declaration of Independence asserted the conviction that all men were created equal, and proceeded to draw an elaborate social contract theory from that premise.

A major theme of inequality has persisted in the American political system from its inception to the present day. This theme touches the issue of race relations. At the time of the Declaration of Independence, the United States already had an elaborate system of plantations and domestic slavery. This situation continued for several decades despite the American affirmation of human equality.

Yet once again it was neither America's political rhetoric nor even a wider and older Christian morality which created conditions for the termination of slavery. It was, in fact, technological change. As the industrial revolution got under way, new techniques of production were perfected, and new methods of trade and exchange evolved between the United States and Western Europe. The latter was finding that the old triangle of trade, involving slaves from West Africa to the Americas and other merchandise between the Americas and Europe, was no longer efficient. The rise of humanitarian concern in Europe was substantially stimulated by the emergence of new methods of production and general technological improvements. It was the teachings of neither John Locke nor Jesus Christ that ultimately created a responsive constituency for the abolitionists in Europe and the Americas. It was the discovery that prosperity no longer needed slavery in the old sense. Thus, it was the new technology, assisted to some extent by the new science, that helped the process of equalization.

The same technology which effectively ended the slave trade nonetheless also helped to expand imperialism. The status of blacks within the Americas was slightly improved after abolition, but within the African continent it was exposed to new levels of penetration and subjugation as a result of the Western world's mastery of the new technology. The various powers of Europe carved out large chunks of the African continent, and human history entered its most elaborate state of feudo-imperial relationships. 
The United States itself did not venture far into the game of outright annexation of territory. There was territorial expansion within the North American continent itself, and there was also the occupation of the Philippines. In general, however, the United States preferred economic imperialism without territorial annexation. Latin America provides an example: having acquired formal independence from Spain and Portugal, it subsequently became increasingly vulnerable to penetration and manipulation by the United States. The Monroe Doctrine, which ostensibly intended to keep European powers from meddling in the affairs of the American hemisphere, became in effect a doctrine to legitimize intervention instead by the United States, creating a relationship certainly akin both to feudalism and to imperialism.

At the global level, the United States grew to become the richest and most industrially developed country in the world. The distance between the United States and a country like Niger, Mali, or Tanzania in terms of affluence and technological sophistication illustrates that powerful tendency of modern technology to widen disparities beyond anything conceived a few generations earlier. The Northern hemisphere as a whole consumed a staggeringly disproportionate share of the scarce resources of the world, conducted the bulk of international trade, consumed a vast amount of raw materials, controlled much of the world's finance, and enjoyed the highest standards of living ever attained in human history. The Third World was overshadowed in both living standards and outright power.

To some extent the relationships between the "have" and the "have-not" nations was a form of interdependence. Primary producers, contributing raw materials and oil and other sources of energy to the manufacturing and industrial plants of the Northern hemisphere, received in return processed goods and products of highly sophisticated technology. It was indeed a system of interdependence, but the interdependence was once again feudoimperial. The rich countries continued to get richer; the poor remained indigent. The Northern hemisphere under the impetus of technological success was widening more than ever the gap existing between itself and the less fortunate sectors of the human race. 


\section{THE STRATEGY OF COUNTERPENETRATION}

The Third World's response to this stratification requires not only a new relationship among Third World countries but also a new relationship between the Third World and the dominant Northern hemisphere if this economic and political dependence is to be broken.

An important school of thought in the Third World has opted for the strategy of disengagement. Under this strategy the countries of the Third World should seek to become self-reliant. When capital is scarce, they should investigate how best to use their own surplus of labor. When advanced skills are scarce, they should use intermediate technology to further develop traditional expertise. There should also be exchange of information and consultation among Third World countries on these modest technological approaches toward solving their problems. It may sometimes make sense to move from the hoe to the plough before one attempts to use the tractor. Both the People's Republic of China and the Republic of Tanzania have been among the countries that have explored the possibilities of self-reliance both by substituting labor-intensive for capital-intensive techniques, and by substituting intermediate technology for the more alluring advanced technology of the Western world.

The doctrine of disengagement as defined and elaborated in the Third World has also put special emphasis on the need for at least partial disengagement from the international capitalist system because the international system of trade and investment is so structured that the full integration of a Third World country can only lead to exploitation. For instance, the movement from the developed world to the developing countries of foreign investment and the encouragement of economic development leads to the enforced purchasing of advanced equipment from the donor countries.

There is in fact an alternative strategy which, though rich in potential, has yet to command the attention of theoreticians and economic and political analysts. This alternative strategy is what we call the strategy of counterpenetration. It involves not a withdrawal from the international capitalist system but an infiltration 
of that system to make it more vulnerable to Third World pressures. If Saudi Arabia had disengaged itself from the international capitalist system, it would not today be enjoying an amount of economic influence at the international level out of all proportion to its size or level of technological skills. By being substantially integrated through its own resources in the international capitalist system, however, Saudi Arabia has gradually built within that system an immense economic leverage.

Until the energy crisis of 1973 it was too readily assumed that a country had to be economically developed to be economically powerful. Countries measured their international leverage substantially in terms of their technological and demographic size, and seldom in terms of their primary economic products. It was equally assumed that, while the workers in individual industrial countries had acquired domestic power through collective bargaining, the poor countries at the international level could not similarly threaten economic action against the Northern hemisphere. The growth of trade unionism in industrial countries was substantially the growth of a system of collective economic "blackmail."

At the international level, however, it continued to seem impossible that pure primary producers could ever acquire a capacity to threaten "economic blackmail" against the Northern hemisphere. The energy crisis, or more specifically, the readiness of the Arabs to use that crisis as a means of exerting international pressure, upset this state of affairs. All of a sudden it looked as if oil as energy could indeed be comparable at the international level to labor as energy at the domestic level. New possibilities of international collective bargaining were now on the horizon.

In reality, Third World leverage against the Northern hemisphere has varied enormously from country to country. Saudi Arabia and Iran have become substantial actors on the international economic scene, but countries like Chad, Malawi, and Haiti remain on the periphery. Similarly, producers of oil might indeed be among the new economic giants of the globe, but this does not make producers of cotton or cocoa equally influential.

Despite immense variations in power, the fact nevertheless remains that a new mood of political international effectiveness 
has emerged for Third World countries. Different subsections are exploring possibilities of establishing cartels of their own in a bid for improved economic justice. The strategy of counterpenetration, therefore, requires not a withdrawal from links with the economies of the Northern hemisphere, but an exploration of the possibilities of making that hemisphere reciprocally dependent in a new way.

Other possibilities of potential counterpenetration exist. The most directly human resource are the pockets of Third World populations within the industrial countries themselves. Until 1973, West Germany imported into its industries large numbers of Southern Europeans. While Southern Europeans are not members of the Third World proper, their relative underprivileged status makes them potential allies of other immigrant workers from outside Europe itself. France has significant populations of Algerians and other North Africans, as well as black Africans, involved in its economic life. The number of these people is still relatively modest, and the energy crisis has interrupted the flow of such migration into the heartlands of industrialized Europe. But the phenomenon itself could be the beginning of human counterpenetration, since the employment of migrant workers has created conditions at once exploitative in the short run and potentially revolutionary in the years ahead.

The most important pocket of the Third World within the heartland of the Northern hemisphere is, in fact, the black American population. Black Americans can be regarded as the second largest black nation in the world, but a black nation which is at the same time part of the most powerful country in the world. The political consciousness of black Americans has increasingly included a sensitivity to Third World status, and an expanding empathy with the peoples of Africa, Asia, and Latin America.

The impact of black Americans on the foreign policy of the United States is still very modest. But its potentialities emerge as considerable once we consider the immense, albeit declining, influence of American Jews. In October 1973, during the Middle Eastern crisis, the United States ordered a nuclear alert, implying a readiness to initiate a nuclear war rather than risk the defeat of Israel. 
Similarly, the United States Senate continues to link the issue of Jewish emigration from the Soviet Union with the issue of what type of economic relationship America should have with Russia. The proposal to extend the most favored nation treatment to Soviet Union has foundered repeatedly in the United States Senate against the rock of Jewish emigration from Russia. The American Senators were correctly asserting that the Jews in Russia were denied the right to emigrate without paying a tax. But these are not American citizens being victimized by the Soviet Union, nor are they Israelis endangered by the Arabs. They are citizens of Russia by birth and descent. The American Senate is under no obligation to take them into account.

The blacks of South Africa are often denied not only the right to emigrate to other lands, but even the right of movement from one part of the same country to another, or one section of the same city to another. Elaborate pass laws within South Africa have been in operation for generations. Movements across racial boundaries, either in terms of marriage or even in terms of visits among relatives and friends, have been drastically curtailed within South Africa.

But, just as there is an enormous difference between an American readiness to commit economic and military resources in defense of the rights of Israelis as against a conspicuous lack of similar commitment in defense of black South Africans or black "Rhodesians," so, too, it is as yet inconceivable that an American Senate would threaten strong economic sanctions against South Africa on the issue of the right of black people to move around within their own country, let alone emigrate to a distant land. The rights denied to many blacks in South Africa are far greater in number and substance than the simple right to emigrate withheld from Soviet Jews.

When American blacks finally attain a level of influence such as that enjoyed today by American Jews, the value of that black American enclave for the Third World will rise dramatically. This black enclave in the mightiest nation in the world would indeed become a powerful instrument of counterpenetration, valuable not only for black Africa but for the Third World at large. 


\section{THE IMPERATIVE OF INEQUALITY WITHIN THE THIRD WORLD}

What emerges from these considerations is the simple proposition that counterpenetration might well be an indispensable mechanism for the ultimate transition from feudo-imperial relationships to mature interdependence. The contradictions of technological imbalance will continue, but the technological and economic superiority enjoyed by the North could still be outweighed by other strategies pursued by the Third World and its enclaves.

The contradictions of technological change also continue. Saudi Arabia is still technologically a backwater in terms of skills, even if it is in the forefront of the production of energy for use in other countries. A mature interdependence would entail a better relationship, based in part on effective mutual vulnerability, between the technologically superior Northern hemisphere and the primary producers in the Southern hemisphere.

If OPEC collapsed, or were at any rate seriously weakened, what effect would this have on the struggle by the Third World for a New International Economic Order of some kind? Is the disarray within OPEC the beginning of a much more serious disarray in the Third World as a whole? At least in the short run, and in spite of the new "price war" within OPEC, the dramatic rise in the power of OPEC since 1973 has had a positive impact on the solidarity of the Third World. Indeed, one of the striking factors on the world scene since then has been the strange paradox of greater economic disparities among Third World countries than ever, combined with greater political solidarity among them.

Until 1973 the terms "developing countries" and "poor countries" were interchangeable. Subsequently, however, the concept of "wealthy underdeveloped countries" is no longer a contradiction. Some analysts have even drawn the conclusion that the term "Third World" is no longer meaningful because of the great disparities among its members. This widening economic gap among the members of the Group of 77 notwithstanding, there is a surprisingly resilient sense of solidarity. 
It is conceivable that some degree of inequality is a necessary precondition for certain forms of solidarity, however fragile they may be. In discussing the North Atlantic Treaty Organization, Altiero Spinelli, ${ }^{1}$ the distinguished Italian Europeanist, once demonstrated the importance of inequality in a political alliance or a "military confederation" (Spinelli, 1962: 543):

NATO is not a classical alliance but rather a true military confederation-an association of states that have decided on a common defense of particular territories, for which purpose they have created representative bodies, as well as various common military services and a common strategy. As with all other confederations which have meant something in history, this one is viable only because it contains one member "more equal than others"indeed, a super-power.

Spinelli also examined the momentum of the European Community in similar terms after World War II. Europe required a central authority which would distribute aid in a way which would promote a balanced recovery of the various countries, ensure that the reconstruction of Germany took place in such a way as not to generate mistrust and disagreement between victors and vanquished, and ensure further that military defense and related foreign policies were harmonized. But, argued Spinelli (1962: 543-544):

Europe, founded on the principle of national sovereignties, was originally incapable of undertaking such tasks alone. The American hegemony, willingly accepted by the European states in the dramatic period after the war, supplied the supranational power which Western Europe needed but did not possess.

Spinelli's thesis is therefore that the relative cohesion of the Western world has rested on the simple fact that the United States was "more equal" than the others. Inequality within the Western world was, in his view, a precondition for viable solidarity.

The question which arises now is whether or not inequality within the Third World as a result of the dramatic rise of affluence among the oil exporters has created at least a temporary founda- 
tion of solidarity. The leadership of the Third World has passed for the time being into the hands of the Arab States. In the 1950s and early 1960s the Third World was led by India and Jawaharlal Nehru. There, too, the massive size of India and the stature of Nehru implied both inequality between India and the rest of the states that were in existence at the time and the possibility of effective leadership by India. But the absence of adequate resources in India great enough to sustain international influence, combined with the death of Nehru, gradually eroded India's capacity in the face of the dramatic multiplication of Third World states in the United Nations in the 1960s. For a while, the Third World was bereft of leadership-until the Arab world captured it in the 1970s.

Major initiatives toward changing the world economy have in the last few years disproportionately originated in the Arab States. The United States, which initially refused to link, for instance, the discussion of oil with a discussion of other raw materials, has more recently retreated from that position.

It would have been easy for the oil producers to limit themselves to a discussion of their own interests with the oil consumers. Yet countries such as Algeria and Iraq have been very aware that Third World producers of cotton, cocoa, or even copper could not exercise the same leverage on the world economy as could the oil producers. The latter thus saw it as their duty not only to improve their own lot but also to help create a new international economic order at a global level. The effectiveness of the oil weapon is bound to be temporary. Oil may get cheaper again as new supplies are discovered or entirely new forms of energy enter the scene. The oil producers have, thus, only a few years in which to consolidate their power. At present the Arab states are rising to the challenge. It remains to be seen whether they will maintain their loyalty and commitment to the more disadvantaged members of the Third World.

Iraq and Venezuela have actively tried to create a system of collective aid for distribution by OPEC to the poorer developing countries. To be sure, many of the Arab states have continued to prefer bilateral aid. At the meeting of the OPEC finance ministers 
in 1975 a decision was reached to establish a development fund for the poorer Third World countries. It was understood that this collective aid would supplement any bilateral efforts between individual donors and their friends rather than replace them. The proportion of aid from OPEC countries within the total aid flows of the world is almost bound to increase substantially in the coming years.

What all this means is that a dual strategy is evolving, led primarily though not exclusively by the Muslim members of OPEC. This dual strategy, first, puts pressure on the industrial countries to redirect the world economic system so as to give greater equity to the poorer Southern hemisphere. The second aspect of the OPEC strategy is to increase its own performance in aiding and facilitating economic development in poorer countries of the Third World. The struggle to create a more equitable world economy may well take a long time. But by the end of the twentieth century, historians may be able to say that, among the factors which helped democratize the world economy, was the emergence of oil power for a brief period in the last quarter of the century.

\section{MATURE INTERDEPENDENCE AND THE DECLINE OF THE WEST}

The debate in the United States about energy conservation is being followed in the Third World with both curiosity and concern. This is because there may be a direct clash between resource conservation by the industrialized countries and prospects for social justice for the Third World. A sustained attempt by the Northern hemisphere (especially North America, Western Europe, and Japan) to reduce its consumption of oil is bound at the same time to mean reduced leverage and influence for the oil producers over the oil consumers. The economic slowdown in the industrialized countries and the strategies of conservation discussed in the West have already resulted in reappraisal by some members of the Organization of Petroleum Exporting Countries about future pricing policy. Iran's ambitious developmental plans 
have also had to be considerably revised as a result of the shortfall in energy production since the revolution. The tone of decision-making within OPEC has become more circumspect, a little more cautious.

Yet the OPEC countries probably have little more than a decade to exert leverage on the industrialized countries in the direction of a more equitable international economic order. A policy of further restraint in consumption by the Northern hemisphere would weaken OPEC leverage even further. The Northern hemisphere's readiness to respond to arguments is often in direct proportion to its own sense of vulnerability. Industrial giants that are still hungry for energy and raw materials from less developed countries are more vulnerable than those that have acquired the discipline of restraint and economy. Thus, it is important that for at least another generation the Northern hemisphere's appetite for energy and raw materials should remain relatively unabated and that its dependence on the countries which produce those resources will increase. After all, interdependence means mutual need of each other. As the United States continues to increase the proportion of imported oil for domestic consumption, America's responsiveness to some pressures from her external sources of energy should grow, and the old pattern of relationships between the dominant North and the underdeveloped South might at last be transformed.

Indeed the world may already be on the verge of that ultimate transition from feudo-imperial interdependence to more mature balance. Within the Southern hemisphere itself primitive interdependence is still struggling to maintain at once a sense of solidarity and a sense of equality among the constitutent parts. As the century moves through its last quarter, primitive interdependence within the Third World might indeed remain to serve the functions of creating mature interdependence between the Third World and the developed states. And with the arrival of that maturity, that fulfillment in human interaction, the link between the problem of equality and tensions of interdependence might at last enter an era of compatibility. 


\section{NOTE}

1. Spinelli was at the time Delegate General of the Congress of the European People and Secretary General of the Italian branch of the Movement of European Federation.

\section{REFERENCE}

SPINELLI, A. (1962) "Atlantic pact or European unity." Foreign Affairs 40 (July): 542-552.

Ali A. Mazrui, D. Phil. (Oxon), is Director of the Center for Afroamerican and African Studies and Professor of Political Science, University of Michigan, Ann Arbor. He is a former Vice-President of IPSA, Past President of the African Studies Association of the United States, and Vice-President of the International Congress of African Studies. Among his numerous writings, the following are most relevant to this article: $A$ World Federation of Cultures: An African Perspective, 1976; Africa's International Relations, 1977; The African Condition (B.B.C. 1979 Reith Lectures), 1980. His address is Center for Afroamerican and African Studies, University of Michigan, 909 Monroe, Ann Arbor, Michigan 48109, U.S.A. 